\title{
Antibiotic Resistance of Streptococcus mitis Isolated from Dental Caries Patients in Missan City
}

\section{Mohammed A. Abd Ali ${ }^{1}$, Sami. KH. Jabar', Sundus A. Abd Ali ${ }^{3}$}

${ }^{1}$ Biology Department, College of Science, Missan University, Iraq

${ }^{2}$ College of Dentistry, Missan University, Iraq

${ }^{3}$ Health center, Missan, Iraq

\begin{abstract}
Summary: Twenty six isolates of Streptococcus mitis bacteria collected from clinical of dental disease in missan city, then analyzed between (October and December in 2014).The samples taken in order to determine the bacterial profile and antibiotic susceptibility. Isolates of Streptococcus mitis were tested against eight different antibiotics and crude of crude aqueous extracts from flowers of Matricaria chamomilla L., by a disk diffusion method. 100\% of isolates were resistat to the Tetracycline ,84\% resistant to Ampicillin , 96\% resistant Nitrofurantion ,100\% resistant to Optochin ,80\% resistant to Bacitracin ,96\% resistant to, $92 \%$ resistant to Vincomycin, $73 \%$ resistant to Benzypenicillin where found to be the least effective antibiotics against MDR Streptococcus mitis. Also the antimicrobial suscepitility of isolates where tested against crude of crude aqueous extracts from flowers of Matricaria chamomilla L. with different concentration $(62,5,125,250,500 \mathrm{mg} / \mathrm{ml})$ detected by agar well diffusion methods, the aqueous extracts from flowers of Matricaria chamomilla L. have more effective in $500 \mathrm{mg} /$ $\mathrm{ml}$. Finally cytotoxicity evaluating toward human RBC, the results revealed these crud extracts of Matricaria chamomilla L. have not any cytotoxicity in all concentration. The good antimicrobial potency of crud extracts of Matricaria chamomilla L. indicates the treatment of MDR Streptococcus mitis as an alternative to the costly antibiotic.
\end{abstract}

Keywords: Antibiotic, MDR Streptococcus mitis, Minimum Inhibitory Concentration (MIC), Matricaria Chamomilla L. Flowers

\section{Introduction}

The oral cavity is a complex econsystem comprising many coated with a wide variety of species (Chopde et al.,2012). Viridans Streptococcus and other alph -hemolytic Streptococcus have been reported with increasing frequency to cause infection. Streptococcus characteristics are Gram positive cocci (spherical or ovoid ) often occurring in pairs and chains Streptococcus are facultatively anaerobic and catalase negative, on blood agar, the species exhibit various degrees of haemolysis, which can to be used as an early step in identifying clinical isolates. Streptococcus mitis, one of the species included among viridians Streptococci, is the most resistant to beta-lactam antibiotics of this group (Doern et al., 1996). Streptococcus mitis groups, although surgical drainage is of primary importance, administration of antimicrobial therapy becomes necessary in serious infections and. (Lewis et al.,1995). However, many attempts for prevention of dental caries were of on practical use up to the present .

Antibiotics are chemical substances considered as secondary metabolites producing by microorganisms during stationary phase. They have the ability to kill or inhibit other microorganisms (Atlas,1996). The antibiotics are divided into groups according to their mode of action, include the bacterial cell wall, cell membrane ,protein synthesis and nucleic acid synthesis (Elliott et al.,2007). Antibiotics such as penicillin and erythromycin have been reported to effectively prevent dental caries in animal and humans (Jonathan et al.,2000) ,but they are never used clinically because of many adverse effects such as hypersensitivity reaction, suprainfections and teeth stainng.The most frequently isolated facaltatively anaerobic microorganisms were the oral streptococci, in particular those belonging to the 
former Streptococcus mitis group and milleri groups.(Ghiteseu,1997) .

Normal products have been used for thousands of years as most of the oral diseases are due to bacterial infection and it has been well documented that medicinal plants confer considerable antibacterial activity against various microorganisms(Saeki et al ., 1989). This study investigated evaluate the antibacterial activity ofcrude extract of the leaves of Matricaria chamomilla L., against Streptococcus mitis. With found minimum inhibition concentration of extracts with Biofresh mouth wishes.

\section{Material and Methods}

The project was approved by the Department of biology in college of sciences /Missan university / Iraq

Isolation and Identification of Sreptococcus mitis 26 isolates of Srep.mitis were isolated from caries patients . a sterile cotton swab was used. Samples were cultured on blood agar medium, incubated in gar under co 2 at $37^{\circ} \mathrm{c}$ overnight, the colony appeared then subcultured and purified. Identification of the isolates based on many characters such as colonial morphology, Gram stain , motility, oxidative , fermentation test, catalase citrate and oxidative tests, Strep mitis isolates were stored in Nutrient broth (Johnl et al.,2003 ).

\section{Antibiotic susceptibility testing :}

Agar disc diffusion test were done for all the isolated (Kirbe Bauer, 1966 ). A suspension of each isolate was made at turbidity to $0.5 \mathrm{McF}$ arland standard and then plated on to Muller - Hinton agar Plate. Antibiotic disc, was applied to each plate. The plates incubated at $37^{\circ} \mathrm{c}$ for $24 \mathrm{~h}$.After incubation the inhibition zone was measured, the results of all isolates compared with standard isolates of Streptococcus mitis were isolated from dental carries patients. Plant Material Matricaria chamomilla L. [ Figure 1] was collected from the market in amara city , and taken to the laboratory. The Plant materials (Fruit ) were washe separately under running tap water, followed by rinse using sterilized distilled water. Excess of was removed from the plant material using filter paper before they were used for extraction.

\section{Antibiotic susceptibility assay :}

The well diffusion assay is suitable for aqueous extracts because they are difficult to dry on paper discs (Tadeg et al.,2005). A suspension of each isolate was made at turbidity equal to $0.5 \mathrm{McF}$ arland standards and then plated on Muller- Hinton agar. Antibiotic disc was applied to each plate .The plate incubated at $37^{\circ} \mathrm{c}$ for $24 \mathrm{~h}$ in rich $\mathrm{co} 2$. After incubation the inhibition zone was measured the results of all isolates compared with standard isolates of Streptococcus mitis were isolated from caries patients.

\section{Preparation of aqueous extracts:}

The extracts were prepared according to (Ahmad et al., 1998). 25gram of finely powdered material and $400 \mathrm{ml}$ of distilled water were refluxed in $500 \mathrm{ml}$ flask and suspension was put on Magnatic stirrer plate for 24 hours at room temperature, the extract then filtered by using filter paper type Whattman , No1. And dried at room temperature $25^{\circ} \mathrm{c}$. then scratched by sterilized clean knife . After that it has been weighted to be kept in refrigerator until it has been used.

\section{Determination of MIC by agar plate dilution method:}

According to the methods of NCCLS ,(2002), agar plate dilution test was used to determine the Minmum Inhibtory Concentration (MIC) of an antimicrobial agent.

Cytotoxicity assay :

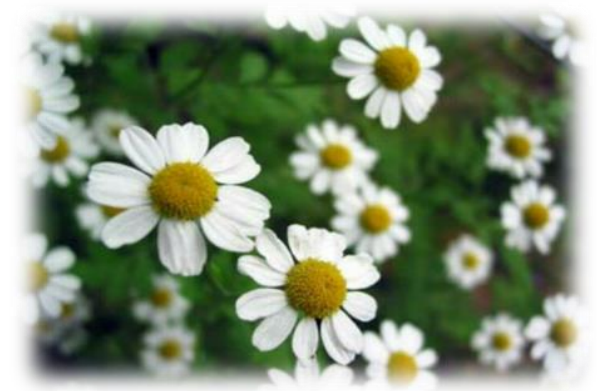

According to the methods of Xian - Guo and Ursula (1994),human red blood cells were used for toxicity test. (Figure 1) Matricaria chamomilla L. Flowers 
Antibiotic Resistance of Streptococcus mitis Isolated from Dental Caries Patient in Specialist Centre for Dental Health - Missan City

Table [1] :Antibiotics: eight type of antibiotics used in this study:

\begin{tabular}{|l|l|c|c|}
\hline No & Antibiotic & Concentration & Company \\
\hline 1 & Tetracycline & TE10 $(\mathrm{mcg})$ & \\
\hline 2 & Ampicillin & AM $(\mathrm{mcg})$ \\
\hline 3 & Nitrofurantion & F100 $(\mathrm{mcg})$ \\
\hline 4 & Optochin & Op5 $(\mathrm{mcg})$ \\
\hline 5 & Bacitracin & B10 $(\mathrm{mcg})$ \\
\hline 6 & Erythromycin & E15 $(\mathrm{mcg})$ \\
\hline 7 & Vincomycin & VA30 $(\mathrm{mcg})$ \\
\hline 8 & Benzylpenicillin & Be10 $(\mathrm{mcg})$ \\
\hline
\end{tabular}

Table (2 ) Distribution of bacterial isolates diagnosed by species Streptococcus viridans bacterial oral cavity.

\begin{tabular}{|l|l|l|l|}
\hline Total Number & $\begin{array}{l}\text { Total Number } \\
\text { of isolated }\end{array}$ & \multicolumn{2}{|l|}{ Number \&type of Streptococcus viridans strains } \\
\hline \multirow{3}{*}{44} & \multirow{3}{*}{26} & $(11) 42.3 \%$ & Streptococcus mitis \\
\cline { 3 - 4 } & & $(10) 38.4 \%$ & Streptococcus orails \\
\cline { 3 - 4 } & $(2) \quad 7.6 \%$ & Streptococcus suis \\
\cline { 3 - 4 } & & $(1) 3.8 \%$ & Streptococcus canis \\
\cline { 3 - 4 } & $(1) 3.8 \%$ & Streptococcus gallolyticus \\
\cline { 3 - 4 } & $(1) 3.8 \%$ & Streptococcus pneumonia \\
\cline { 2 - 4 } & &
\end{tabular}

Table (3): Susceptibility of Streptococcus mitis to eight type of antibiotics

\begin{tabular}{|l|c|c|c|}
\hline No & Antibiotics & $\begin{array}{c}\text { Resistant } \\
(\mathrm{NO})\end{array}$ & $\begin{array}{c}\text { Resistant } \\
(\%)\end{array}$ \\
\hline 1 & Tetracycline & 26 & $100 \%$ \\
\hline 2 & Ampicillin & 22 & $84 \%$ \\
\hline 3 & Nitrofurantion & 25 & $96 \%$ \\
\hline 4 & Optochin & 26 & $100 \%$ \\
\hline 5 & Bacitracin & 21 & $80 \%$ \\
\hline 6 & Erythromycin & 25 & $96 \%$ \\
\hline 7 & Vincomycin & 24 & $92 \%$ \\
\hline 8 & Benzylpenicillin & 19 & $73 \%$ \\
\hline
\end{tabular}

Table (4) The mean of inhibition zone of aqueous of crude extracts from flower of Matricaria chamomilla $\mathbf{L}$ against multi-drug isolated against Streptococcus mitis

*clinical strain

** mean of three value each number 
Antibiotic Resistance of Streptococcus mitis Isolated from Dental Caries Patient in Specialist Centre for Dental Health - Missan City

Table (5). The MIC of the aqueous extracts of crude extracts from flower of Matricaria chamomilla L.

\begin{tabular}{|l|c|c|c|c|c|c|c|}
\hline \multirow{2}{*}{ Sample } & \multicolumn{7}{|c|}{$\begin{array}{c}\text { Dilution of aqueous extracts of crude extracts }(\mathrm{mg} / \mathrm{ml}) \\
\text { Matricaria chamomilla L. }\end{array}$} \\
& \multicolumn{7}{|c|}{} \\
\cline { 2 - 8 } & $\geq 64$ & $\geq 32$ & $\geq 16$ & $\geq 8$ & $\geq 4$ & $\geq 2$ & $\geq 1$ \\
\hline Streptococcus mitis & - & - & + & + & + & + & + \\
\hline
\end{tabular}

Table (6).The MIC of Biofresh mouth wishes

\begin{tabular}{|l|c|c|c|c|c|c|c|}
\hline Sample & \multicolumn{7}{|c|}{ Dilution of Biofresh } \\
& \multicolumn{7}{|c|}{} \\
\cline { 2 - 9 } & $\geq 64$ & $\geq 32$ & $\geq 16$ & $\geq 8$ & $\geq 4$ & $\geq 2$ & $\geq 1$ \\
\hline Streptococcus mitis & - & - & - & - & + & + & + \\
\hline
\end{tabular}

\begin{tabular}{|l|c|c|c|c|}
\hline Bacterial strain isolated & ** The mean of inhibition zone of aqueous of crude extracts \\
& \multicolumn{4}{|l|}{ (mm) } \\
\cline { 2 - 5 } & $62.5 \mathrm{mg} / \mathrm{ml}$ & $125 \mathrm{mg} / \mathrm{ml}$ & $250 \mathrm{mg} / \mathrm{ml}$ & $500 \mathrm{mg} / \mathrm{ml}$ \\
\hline *Streptococcus mitis & 10.6 & 19.3 & 21.0 & 24.8 \\
\hline
\end{tabular}

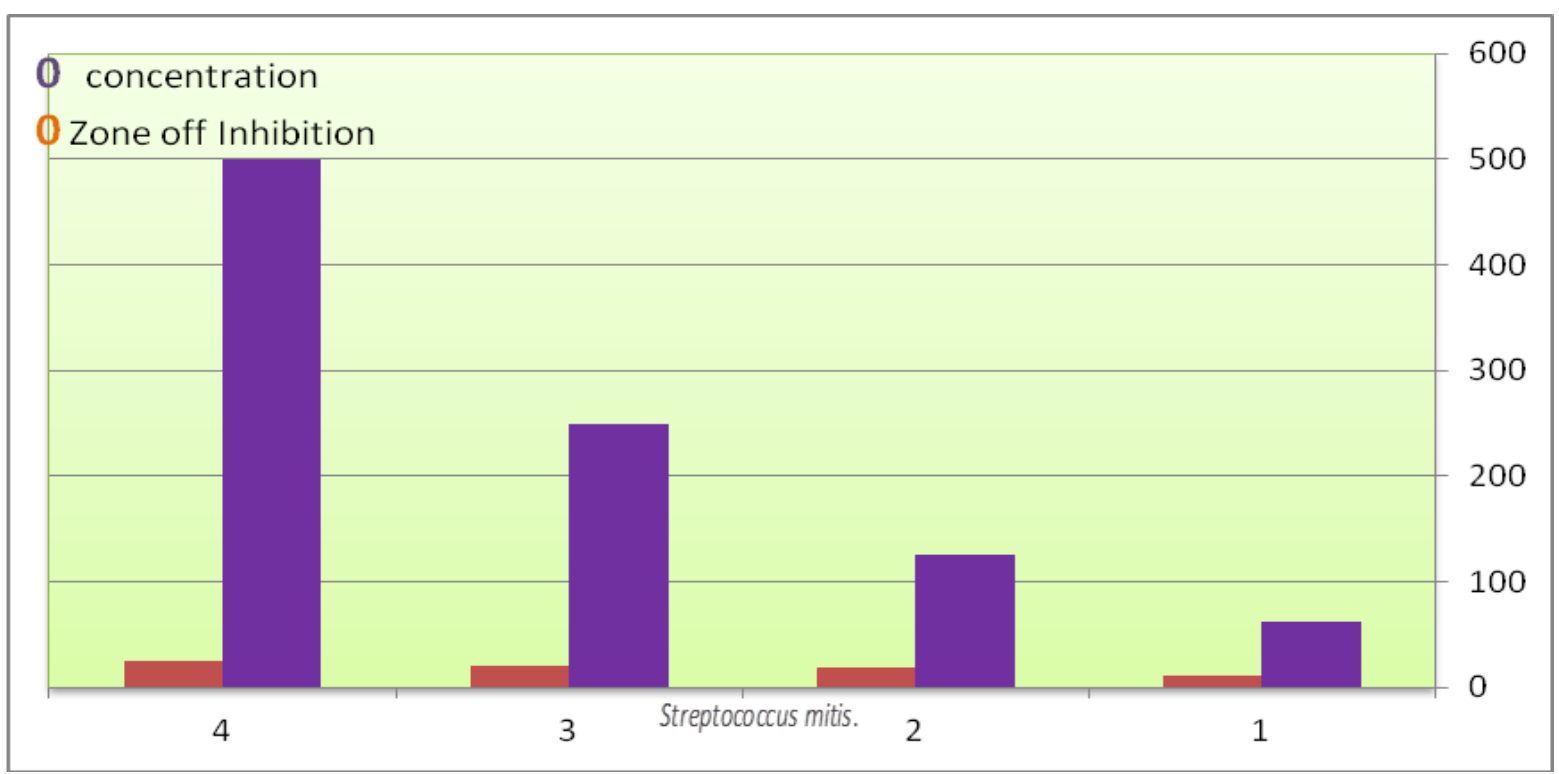

Figure (5): Effect of different concentration of crude extracts from flower of Matricaria chamomilla L. against pathogenic Streptococcus mitis. 
Antibiotic Resistance of Streptococcus mitis Isolated from Dental Caries Patient in Specialist Centre for Dental Health - Missan City

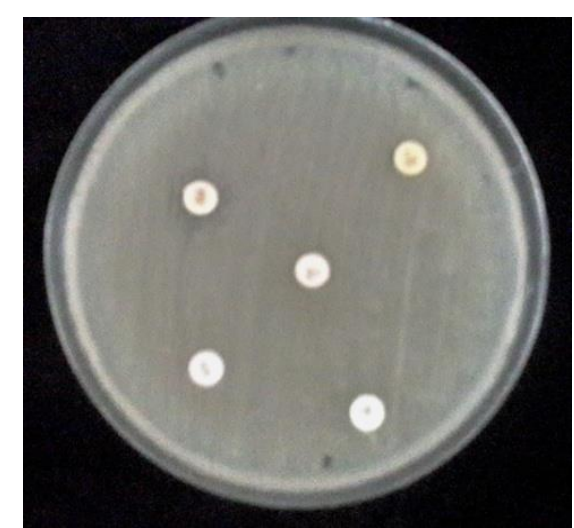

Figure 2: Mueller Hinton agar media with antibiotic sensitive disc showing Streptococcus mitis resistant to all antibiotics
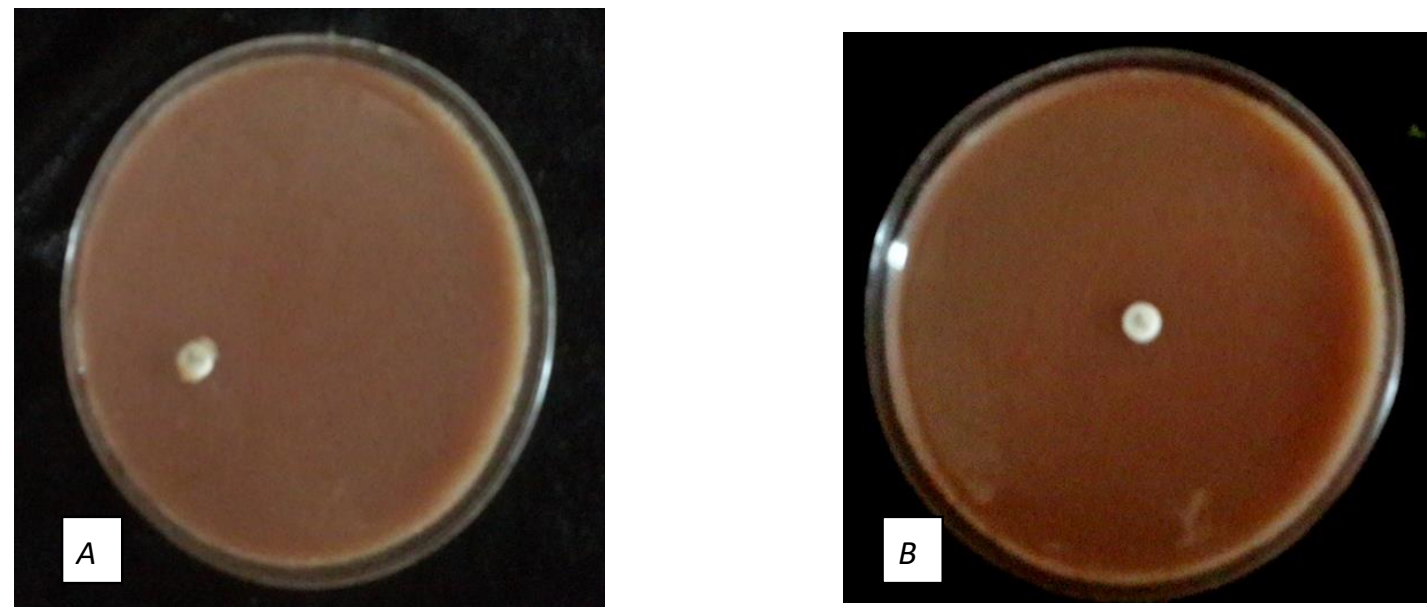

Figure 3 showing Streptococcus mitis resistant Optachin antibiotics (A ) on chocolate agar( B) on blood agar media.

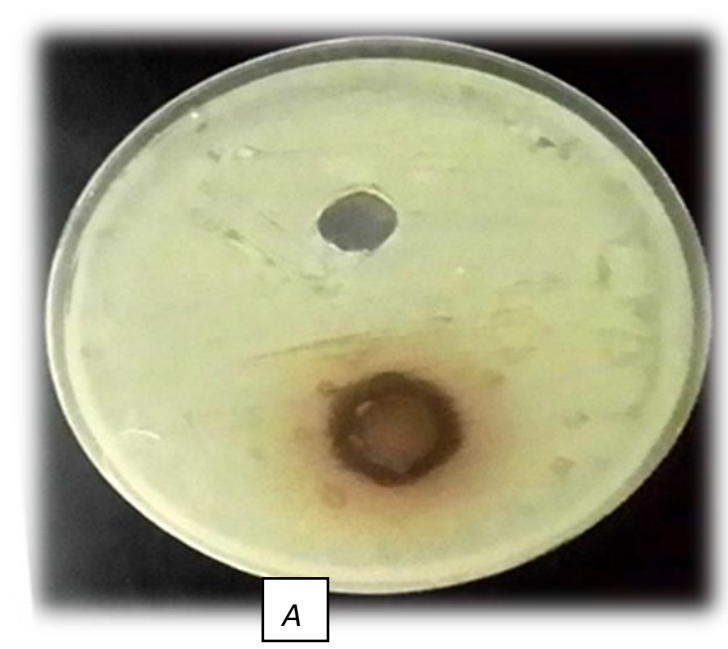



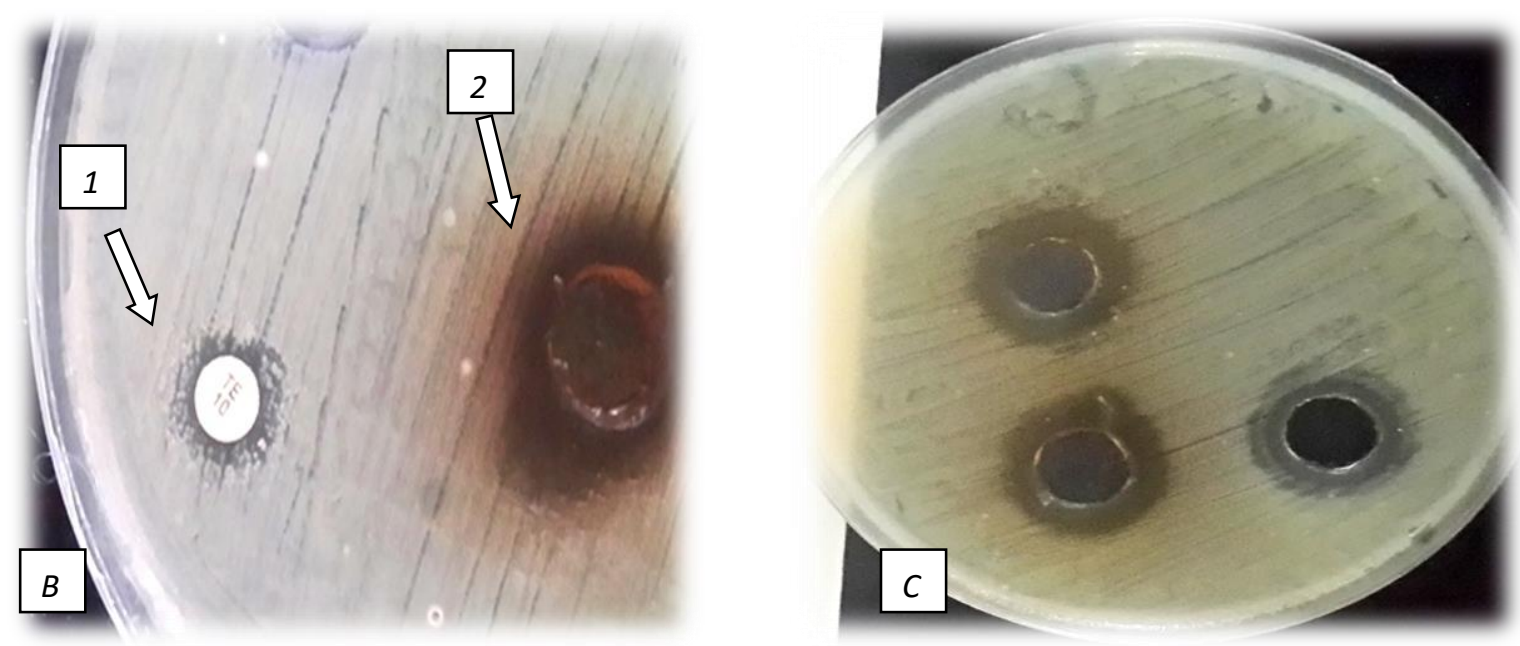

Figure 4: (A) Shown aqueous extract of Matricaria chamomilla L. , Tetracycline resist ant(arrow ) and sensitive (arrow 2 shown aqueous extract in $500 \mathrm{mg} / \mathrm{ml}$ ) , (c) shown aqueous extract in $250,125,62.5 \mathrm{mg} / \mathrm{ml}$ against Streptococcus mitis MDR isolates.

\section{Results}

Table (2 ) shown the distribution of 26 bacterial isolates were diagnoses by species of Streptococcus virdans ,42.3\% Streptococcus mitis , 38.4\% Streptococcus orails , $7.6 \%$ Streptococcus suis , 3.8 $\%$ Streptococcus canis , $3.8 \%$ Streptococcus gallolyticus , $3.8 \%$ Streptococcus pneumonia.

Table (3 )showed high resistance to Optochin (100) and Tetracycline (100\%) , Ampicillin (84\%) ,Nitrofurantion (96\%) , Bacitracin (80\%) ,Erythromycin (96\%) , Vincomycin (92\%) , Benzylpenicillin (73\%) . Multi - Drug resistant strain of Streptococcus mitis were recorded from dental caries patient.

All collected Streptococcus mitis isolated from dental caries patient were exposed to different concentration of aqueous extract of Matricaria chamomilla L. as described in table (4).

The results represented in table (4). Showed that inhibition zone of Streptococcus mitis isolated bacteria increased as the concentration of aqueous extract of Matricaria chamomilla L. increased, the susceptibility pattern to extracts on Streptococcus mitis isolated bacteria maximum inhibitory zone at $500 \mathrm{mg} / \mathrm{ml}$ which was mean $24.8 \mathrm{~mm}$ but in low concentration which was mean $10.6 \mathrm{~mm}$ against Multi - Drug isolated bacteria Streptococcus mitis.

In same time the results represented in table (5 ),(Figure 5 ), showed the MIC of the aqueous extracts of crude extracts from flowers of Matricaria chamomilla L recorded as $(\geq 16 \mathrm{mg} / \mathrm{ml})$, whale the results represented in table (6) showed the MIC of Biofresh mouth wishes recorded as $(\geq 4 \mathrm{mg} / \mathrm{ml})$.

\section{Discussion}

Our study showed high prevalence of bacterial infection especially MDR- Streptococcus mitis among dental caries patient. This study was focused on the susceptibility testing of clinically isolates belonging to mitis group since these microorganisms are frequently isolated from oral and maxillofacial infaction (Renneberg et al .,1997).

Viridans Streptococcus are normal inhabitants of the human oral cavity. The portal of entry for the organisms is usually an oral lesion. Systematic infections can still occur in patient without overt oral lesions. The Viridans Streptococcus highly resistant to penicillin, Streptococcus mitis in particular, as a cause of sepsis in patients. The relevant mechanism of penicillin resistace in Viridans Streptococcus might be the patients with lowered affinity for beta - lactam antibiotics (Doern et al.,1996). The results prevalence of Streptococcus mitis isolated and new resistant strains, the resistant was detected against Tetracycline (100\%) , Ampicillin (84\%) ,Nitrofurantion (96\%) , Optochin (100\%) ,Bacitracin (80\%) , Erythromycin (96\%) ,Vincomycin (92\%), Benzylpenicillin (73\%) [ Table 3 Figure $3,4,5]$ this results are agreement with other studies carried out in Romania (Bancesu et al.,2004) 85 isolated of the 151 sample studied belonged to Streptococcus mitis group .

There are four main mechanisms by which bacteria become resistant to antibiotics agents, Destruction and inactivation of the antibiotic by blockage of 
transport of the agent into the cell providing the cell with a replacement for the metabolic step inhibited by the drug, and protection of the target site by a bacterial protein therefore it is imperative to seek other sources of therapeutic aents(Lambert,2005). In this study, agar well diffusion method was used to determine the antibacterial activity of the crude extracts of flowers of aqueous extract of Matricaria chamomilla L. in [table 4 , Figure 4,5] shows the activity of different concentration $(62.5,125,250$ and $500 \mathrm{mg} / \mathrm{ml}$ ) which increased the inhibition zone against MDR Streptococcus mitis bacteria, the growth inhibition of bacteria increased as the concentration of extract increased, the susceptibility pattern to the extract on Streptococcus mitis isolated expressed maximum inhibitory zone at concentration $500 \mathrm{mg} / \mathrm{ml}$ which was $24.8 \mathrm{~mm}$, while the low concentration of aqueous extract of Matricaria chamomilla L. recorded $10.6 \mathrm{~mm}$ as in Table 4 Figure4 ,5] that's result agreement with (وكت , (و اخرون ,

Finally a test was also carried out to examine the cytotoxicity assay by using (Xian-guo and Ursula 1994), methods towards human red blood cells in which the crude extracts of of aqueous extract of Matricaria chamomilla L., where found that they are not having any cytotoxicity an (1-500mg / ml) . Results of this study suggest that the crude extracts of of aqueous extract of Matricaria chamomilla L. may be useful either alone or when combined with antimicrobial agents to treat (MDR) Streptococcus mitis bacteria

\section{Acknowledgments}

The authors are grateful to the microbiology team in Alsader hospital Specialist Centre for dental health and they sincerely thank the dental disease patient in Missan city.

$$
\text { 1- المر العربية , مؤيد صبري و علي , عبد الامة بركة و فرحان }
$$

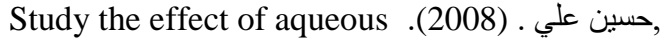
extracts of some Plants on a cute and chronic gingivitis .

\section{Referances}

1. Atlas,R; Parls , L. and Baron , A.(1995).Laboratory manual of experiential Microbiology .1 ed Mosby, Ine . Missouri

2. Bancescu , G.. ; Dumitriu ,S. ; Defta , M. (2004). Susceptibility testing of Streptococcus mitis group isolates. Indian J Med Res 119 (Suppl) May 2004, pp 257-261

3. Chopde , N.;Jawale ,B. ; Phanade ,B.(2012). Microbial characterization and their relation with potential identification in patient with denture stomatitis ,J.of Contemporary Dental Practice , vol .13.pp.456-159. http://dx.doi.org/10.5005/jpjournals-10024-1168

4. Doern ,G. ; Tiarans ,M. ; Brneggemann ,A.(1996).Emergence of high rate of antimicrobial resistance among viridans group Streptococcai in United States Antimicrob Agent. Chemother.40:891-4.
5. Elliott ,T. ;Worthington ,T. ; Osman ,H. and Gill ,M. (2007). Medical Microbiology and infection 4ed , Blackwell Publishing Ltd, Oxford, UK.

6. Ghitesen ,J. ; Bucharest, C. (1997). Antibiotherapy.

7. Johan ,P.; Harley , I. ; Prescott ,M. (2003) . Laboratory Exercise in Microbiology .McGraw-Hill.USA.pp.484,1491538 .

8. Jonathan EK, Anna KJ, Johannes VS. Zulu medicinal plants with antibacterial activity. J Ethnopharmacol. 2000; 69: 241 6. http://dx.doi.org/10.1016/s0378-8741(99)00147-6

9. Saeki Y, Ito Y, Okuda K.( 1989). Antimicrobial action of natural substances on oral bacteria. Bull Tokyo Dent Col. 30:129-35

10. Kirby ,W. ; Bauer ,A. (1966). Antibiotic Susceptibility Testing by a standardized single disk method Am .J. Clin .Pathol.45(4)493-496.

11. Lewis ,M. ; Parkhnrest, C. ; Douglas , C.(1995). Prevalence's of penicillin resistant bacteria in acute supportive oral infection .J. Antimicrobial Chemoiler . 35:785-91.

12. Lambert , P. (2005). Bacterial resistance to antibiotic :Modified target sites, Adv. Drug. Delive . Rev,57 (10):14711485. http://dx.doi.org/10.1016/j.addr.2005.04.003

13. NCCLS.(2002). Performance Standards for Antimicrobial Disk Susceptibility Testing .Twelfth information Supplement

14. Renneberg ,J. ; Niemann ,L. ; Gutsehik ,E. (1997) Antimicrobial suscepitipllity of 278 Streptococci blood isolates to seven antimicrobial agents. J.Antimicrob Chemother .30.135-40.

15. Tadeg , H. ; Mohammed ,E. ; Asres , K. ; Geber-Mariam T.(2005). Antimicrobial activities of some selected tradition Ethiopian medicinal plants used in the treatment of skin disorders .J.Ethanopharmacol.43:173-177. http://dx.doi.org/10.1016/j.jep.2005.02.031

16. Xian-gou, H. and Ursula, M.(1994). Antifungal compound from Solanum nigrescens .J. Ethano Pharmacology . 43: 173177. http://dx.doi.org/10.1016/0378-8741(94)90039-6 